It is estimated that two tracks which appear identical must be formed within 1/50 sec. of on $\theta$ another. The chamber is set off by the counters, on an average, once in 12 minutes, so that the probability of the random simultaneous appearance of two non-associated rays is of the order $3 \times 10^{-5}$.

An electron capablo of passing through $2.5 \mathrm{~cm}$. of lead without sensible deviation by ordinary scattering must have an initial energy greater than $10^{\circ}$ e.v. Tho probability that only a single electron of high energy would emerge from the $2.5 \mathrm{~cm}$. plate may be calculated from cascade theory as 0.007 for a $10^{\circ}$ e.v. particle and negligibly small for ono of higher energy. Tho particles which penetrated $15 \mathrm{~cm}$. of lead could not be electronic.

J. G. IVilson ${ }^{1}$ has calculated that tho probability of a meson producing a knock-on proton of high energy is much too small to account for our photograplis, and any process by which one proton knocks. on another would bo expected to give rise to a number of slow protons distinguishablo as heavy tracks. No such tracks have been observed.

We consider that our photographs are best regarded as evidence for meson pairs.

$$
\begin{aligned}
& \text { Birkbeck College, } \\
& \text { London, E.C.4. }
\end{aligned}
$$

Nov. 17.

H. J. J. BraDdick.

G. S. Hensby.

$\therefore$ By private communication.

\section{Occurrence of Greenockite in the Mendips}

Artrнouar small amounts of greenockite (carmium sulphide) have been found in Scotland associated with zinc blende, the mineral has rarely been found in England. In July last one of us (A. W. G. K.) was examining blende from a small dump at somo old workings at a hamlet called Green Ore near Chewton Mendip. The area was at one time worked for calamine (zinc carbonate) and most of the material of the dump consisted of this; but blende, galena and barytes wero also present.

Thin layers of a yellow mineral, ranging up to about $1 \mathrm{~mm}$. in thickness, wero noticed in various small patches in the blende. These were afterwards examined spectroscopically and chemically and proved to be greenockite. There appears to be no record of the mineral having been observed in the Mendips before this.

Cumberland Lndge,

Arthur W. G. Kingsbury.

Bathwick Hill,

Bath.

\section{Central Technical College, Birmingham.}

J. NewtoN Friend. Nov. 15.

\section{A New British Locality for Fluorite in Somerset}

Arthodgh small amounts of fluorite were recorded many years ago from the Avonian Limestone of the Avon Gorge at Clifton, it does not appear to have been found there again, or to have been previously recorded from any part of the Carboniferous of the adjoining Mendip Hills.

In Novemher last year, I found minute traces of a dark purple granular mineral in a disused quarry in Shipham Gorge, near Axbridge on the south side of the Mendips. Subsequent tests showed this to bo fluorite, but the amount was too small for satisfactory examination.
This year. however, further search has resulted in the collection of a number of small but well-formed crystals. These crystals range in colour from colour. less to almost black, purple and mauve shrdes being the only ones so far noticed : they are all small, the largest boing about $3 \mathrm{~mm}$. across the cube face. The sample cube, a $\{100\}$, and the low 4 -faced cube, $f\{310\}$, are the most frequent forms. but combinations of these two also occur. Some crystals recently found are very complex; many crystals are well zoned and in some specimens the fluorite crystals are accompanied hy beautiful littlo bright crystals of chalcopyrito and little velvety black hemispheres of hamatite.

The fluorite appears to be confined more or less to one band in the quarry and occurs in granular calcite filling vesicles in the black limestone of the $C$-zone. These vesicles are numerous, but the majority appear to contain no trace of fluorite.

Careful search in this and other parts of the Mendips over $n$ number of years has failed to produce any other sperimens, and so far this appears to be tho only locality in the district.

Cumberland Lodge,
Bathwick Hill,
Bath. Nov. 15.
ArtuUr W. G. Kinasbery.

\section{Estrogen Depot Formation}

Is a recent communication, Zondek and Sulman ${ }^{1}$ showed that, unlike vestrone, the hormone esters and stilbcestrol in oil, when injected into the rat, remain at the site of injection for a considerable time and from there are slowly absorbed.

Some time ago I undertooli an investigation into the local effect upon the vaginal epithelium of the ovariectomized mouse of small doses of œstrone in arachis oil. The preliminary results showed little of interest, and the inquiry was put aside under pressure of other work. At the timo I noticed, however, that a few control mice which received small doses of arachis oil alone, anil showed little or no effect when the dose was injected into the body wall, did show proliferation of the vaginal epithelium, resembling that preceding œstrus, when the dose was injected into the perineum. The results are shown in the accompanying diagram. With doses of oil of from 0.0025 c.c. to 0.005 c.c. after times between 24 and 48 hours, the height of the epithelium is increased. This increase is a good deal more noticeable when the dose is administered in the perineum than when it is injected into the body wall.

From this it appears that (1) arachis oil, or some part of it. has the property of initiating some proliferation of the epithelium lining the vagina of the ovariectomized mouse; (2) this effect is rather localized.

The localization of the effect of the oil may in all probability be taken to indicate that the oil, or some fraction of it. forms a depot at the site of injection and is not distributed immediately all over the body. If this is so, then it may be that the depot-forming qualities of the solvent have some bearing upon the depot-forming qualities of the œstrogenic injection as a whole. The depot-forming qualities of arachis oil appear to have been made plain in these experiments through the accident of its effect upon this epithelium, which can be measured. It may bo that some œstrogens, for example the esters mentioned and also stilbœstrol, simply tend to remain dissolved 